\title{
Adelskap forplikter: Norges deltakelse i Unescos skoleforsøk 1953-1959
}

\author{
Christian Sale
}

\begin{abstract}
Noblesse Oblige: Norway's Participation in Unesco's Educational Experimental Program 1953-1959. In 1953, Unesco initiated a teaching experiment project, "Co-ordinated Experimental Activities in Schools of Member States of UNESCO," with object to develop an effective and coherent, cross-national "education for peace." Norway was one of 15 countries that accepted the invitation, and put great effort into the project on a national level throughout the 1950's. Where earlier research has focused on the hands-on implementation of the experiments, this article targets the background and motivation for the Norwegian participation. By focusing on key participants and organizational structures framing the experiments, the article argues that the Norwegian efforts to a significant extent should be seen as part of a broader Norwegian policy towards building cultural relations with other countries. An overall ambition for this policy was to promote the Norwegian educational system as an expression of a particular Norwegian democratic and peace building tradition. This also reflected a self-image that resulted in much of a noblesse-oblige-approach towards Unesco, where Norway, together with its Nordic counterparts, felt obligated to offer their assistance.
\end{abstract}

Keywords • associated schools project, Unesco, education for peace [fredsundervisning], cultural relations [kulturelle relasjoner], nordic cooperation [nordisk samarbeid]

\section{Innledning}

Unesco ble etablert i 1946 med mål om å arbeide for fred og mellomfolkelig forståelse gjennom å fremme internasjonalt samarbeid. ${ }^{1}$ Skole og utdanning var fra starten av et sentralt satsingsfelt. De første årene tok dette arbeidet grovt sett to retninger - en mot revisjon av lærebøker, særlig i historie, og en mot seminarer og konferanser for lærere, skolefolk og ulike fageksperter. ${ }^{2}$ De store ambisjonene bak lærebokrevisjonen viste seg imidlertid å være vanskelig å realisere, og i 1953 kuttet UNESCO bevilgningene til dette arbeidet betydelig. ${ }^{3}$ Samtidig ønsket man seg mer håndfaste resultater fra seminar- og konferansevirksomheten. ${ }^{4}$

I 1953 lanserte derfor Unesco skoleforsøksprosjekt Co-ordinated Experimental Activities in Schools of Member States of UNESCO (heretter Unesco-forsøkene).

1 Unesco Constiution: Introduction.

2 Christian Sæle, Den rette historien: Lærebokkritikk som historiepolitisk redskap (Bergen: Universitetet i Bergen, 2013); Unesco, International Understanding at School: An Account of Progress in Unesco's Associated Schools Project (Leiden: Unesco, 1965).

3 Perrti Luntinen, "School History Textbook Revision by and under the Auspices of UNESCO, Part 1", Internationale Schulbuchforschung, no 2 (1988); Sæle (2013), 51-58.

4 Unesco (1965), 11.

Christian Sale is Associate Professor of History at the Department of Archeology, History, Cultural Studies and Religion (AHKR), University of Bergen, Norway.

Email: christian.sele@uib.no 
Dette representerte en ny og offensiv strategi fra Unesco, hvor man rettet søkelyset mot undervisningen direkte, i stedet for indirekte via lærere, fageksperter eller lærebøker. ${ }^{5}$ Norge var et av 15 medlemsland som takket ja til invitasjonen om å delta, og gikk svært aktivt inn i arbeidet. ${ }^{6}$ I 1957 kulminerte det norske engasjementet, og etter at de siste norske forsøkene var fullført i 1959 forlot Norge i praksis prosjektet. ${ }^{7}$ Dette hadde da (fra 1957) endret navn til Associated Schools Project in Education for International Understanding and Co-operation (ASPRO). Det hadde også endret karakter, mer i retning av et kontaktnettverk for utdanningsinstitusjoner på ulike nivåer. Det var likevel i sterk vekst, og har fortsatt å vokse frem til i dag. ${ }^{8}$ Jeg vil i denne artikkelen tematisere bakgrunnen og motivasjonen for det norske engasjementet $\mathrm{i}$ Unesco-forsøkene 1953-1959.

Det finnes ikke mye forskning på den innledende fasen av det som i dag heter Associated Schools Network (ASPnet). Den forskningen som finnes har ofte hatt praktiske siktemål mot å forbedre og utvikle prosjektet, og har derfor i liten grad vært historisk innrettet. Den er gjerne mer praktisk-pedagogisk orientert, med vekt på det konkrete arbeidet i skoler og lærerkollegier, der spørsmål om organisering, tilrettelegging av undervisning og grad av innflytelse og påvirkning på elevene har stått sentralt. ${ }^{9}$ I den grad motivasjon for deltakelse har blitt adressert, har spørsmålene gjerne rettet seg mot grupper av enkeltaktører, som lærere, skoleledere eller elver, hvor svaret jevnt over har vært at deltakelse i prosjektet er motivert av entusiasme for de verdier Unesco representerer, og vilje til å gjøre en innsats for å spre disse verdiene: "a desire for a better world, a will to help create it, and faith in the importance of education in achieving these aims." ${ }^{10}$

For innsikt i prosjektets historiske utvikling, er man i stor grad henvist til Unescos egne rapporter og oppsummeringer. ${ }^{11}$ Også her ligger hovedvekten på det konkrete arbeidet rundt organisering og utforming, bundet sammen av en fortelling der

5 Elisabeth Teige, "Kan demokrati læres?," i Nye stemmer i norsk pedagogisk humanioraforskning, red. Tone Kvernbekk og Lars Løvlie (Bergen: Fagbokforlaget, 2011a), 179-201.

6 Teige (2011a).

7 På 1980- og 1990-tallet økte igjen den norske interessen, og i toppåret 1995 var 70 norske institusjoner aktive i prosjektet (Unesco, UNESCO Associated Schools Project (ASP) List of Participating Institurions by Region (Unescodoc 1995)).

8 Fra 15 land og 33 skoler opprinnelig, var det i 195520 land og 57 skoler, i 195843 land og 186 institusjoner, i 1966: 55 land 510 institusjoner (Unesco 1965). I 1971 ble navnet igjen endret til Associated Schools Project in Education for International Cooperation and Peace (ASP), før det i 1998 fikk navnet Associated Schools Project Network (forkortet ASPnet). Det offesielle navnet i dag er Associated Schools Network, men der man har beholdt akronymet ASPnet. Nettverket samler i dag mer enn 11000 utdanningsinstitusjoner, fra barnehager til høyere utdanning, fra 182 land. UNESCO Associated Schools Network: Guide for National Coordinators (2018), 4-5.

9 Michele Schweisfurth, "Learning to Live Together: A Review of Unesco's Associated Schools Project Network," International Review of Education 51, nr. 2/3 (2005), 219-34; Teige (2011a); Elisabeth Teige, "Citizenship Education and the Rebuilding of Europe after World War II: The Case of Norway," Virteljahrschrift für Wissenschaftliche Pedagogik, no. 3 (2011b); Christina Borgen, Asssociated Schools Project (ASP): En underøkelse av UNESCOs skolenettverk $i$ Norge (Universitetet i Oslo: Hovedoppgave i Pedagogikk, 1996); Eva Nordland, Evaluering av de norske Unesco nettverksskolene, Rapport nr. 2 (Oslo: Pedagogisk forskningsinstitutt, Universitetet i Oslo 1990); Johs Sandven, "Elevenes reaksjon på skolens program, arbeidsmetode og arbeidsorden," Scandinavian Journal of Educational Research 3, no. 1, (1957a), 181-213.

10 Schweisfurth (2005), 232. Se også Teige (2011a), 185-86.

11 Unesco (1965); Unesco, "Navigators for peace:" Associated Schools Project Network (ASPnet) Historical Review 1953-2003. (Paris: Unesco, 2003). 
entusiasme og innsatsvilje for fredssaken ligger til grunn. Det hittil mest koherente forsøket på å gi en samlet historisk beskrivelse av ASPnet, ble utgitt av Unesco ved 50-års jubileet i 2003. Det er symptomatisk hvordan prosjektet her gjennomgående beskrives som et grasrot-initiativ drevet av entusiastiske praktikere, der Unesco og ASPnet fungerer som inspirator og tilrettelegger:

The scheme started out on a small scale at the grassroots level and driven over five decades, by a growing number of enthusiastic and creative teachers committed to reinforcing the humanistic, cultural, and international dimensions of education in view of world developments. ${ }^{12}$

Den praktisk-pedagogiske organiseringen og tilretteleggingen har også stått i sentrum for det som har vært skrevet om den norske deltakelsen i Unesco-forsøkene på 1950-tallet, og myndighetenes rolle er lite tematisert. ${ }^{13}$ Suarez et al. (2009) viser imidlertid at inngang i prosjektet på nasjonalt nivå ofte vel så mye har handlet om å flagge tilhørighet til og interesse for verdensfellesskapet og de verdier Unesco representerer, det de kaller "symbolic affirmation of world community, international understandig and human rights", som engasjement og begeistring for disse verdiene i seg selv. ${ }^{14} \mathrm{Vi}$ vet at også norske myndigheter var involvert i Unesco-forsøkene, ved å finansiere dem og formelt godkjenne de avvik fra læreplanene som forsøksvirksomheten krevde. ${ }^{15}$ Men vi vet lite om hvilke vurderinger som lå til grunn på nasjonalt nivå i denne prosessen.

Jeg vil i denne artikkelen vise hvordan den norske deltakelsen i Unesco-forsøkene ble rammet inn av og bidro i en bredere utenrikspolitisk satsing på å bygge kulturelle relasjoner med utlandet i disse årene. Dette var en satsing som rommet to motiver: $\AA$ skape et positivt bilde av Norge i omverdenen og å forebygge konflikt. ${ }^{16} \AA$ holde frem det norske skole- og utdanningssystemet sto her sentralt.

Etter en kort redegjørelse for Unesco-forsøkenes formål og utbredelse i Norge, vil jeg gjøre rede for relevante forskningsperspektiver på internasjonalt kultursamarbeid i perioden, og hvordan disse informerer min egen analyse. Jeg vil deretter diskutere hvordan Unesco-forsøkene sto i forhold til tidligere forskning på arbeidet med å bygge kulturelle relasjoner med omverdenen, der Kontoret for kulturelt samkvem med utlandet sto sentralt. ${ }^{17}$ Etter det vil jeg gå særlig inn på to ledende aktører i forsøkene, og studere hvilke motiver de hadde med seg inn i arbeidet. Dette er leder for den norske forsøkskomiteen, Haakon Vigander, og ekspedisjonssjef for skoleavdelingen i Kirke- og Undervisningsdepartementet (KUD) Einar Boyesen.

12 Unesco (1965); Unesco (2003), 5.

13 Teige (2011a); Teige (2011b).

14 David F. Suárez et al., "UNESCO and the Associated Schools Project: Symbolic Affirmation of World Community, International Understanding, and Human Rights" Sociology of Education 82, no. 3 (2009), 197-216.

15 Teige (2011a); Josef Faaland og Haakon Vigander, Tre års undervisningsforsøk etter Unesco-tiltak (Oslo: Gyldendal, 1960).

16 Svein Ivar Angell, "Norge og omverdenen 1945-2010: Fra kulturpleje til omdømmeforvaltning," Økonomi \& Politik, nr. 4 (2014), 26-36; Svein Ivar Angell, "The Office for Cultural Relations: Representing Norway in the Post-War Period," i Histories of Public Diplomacy and Nation Branding in the Nordic and Baltic Countries: Representing the Peripery, red. Louis Clerc, Nikolas Glover og Paul Jordan (Leiden/Boston: Brill Nijhoff, 2015).

17 Angell (2014); Angell (2015). 


\section{"Undervisningsforsøk etter Unesco-tiltak"}

En grunnleggende utfordring på skolefeltet, slik Unesco så det, var fraværet av sikker, forskningsbasert kunnskap om hvordan en undervisning for fred og internasjonal forståelse kunne innrettes på en mest mulig effektiv og hensiktsmessig måte. ${ }^{18}$ Unesco-forsøkene var ment å frembringe slik kunnskap. Dette skulle skje ved at ulike land gjennomførte sammenlignbare undervisningsforsøk etter Unescos anvisninger, der resultatene skulle evalueres og analyseres på en vitenskapelig forsvarlig måte. Målet var å utvikle klare retningslinjer for hvordan en slik undervisning objektivt sett burde legges opp, uavhengig av nasjonal kontekst. Tanken var at helhetlige og velprøvde anvisninger, både når det gjaldt innhold og undervisningsmetoder, lettere ville kunne spres internasjonalt.

I invitasjonen som gikk ut til medlemslandene i 1953, hadde Unesco derfor store ambisjoner for prosjektet. Blant annet skulle det omfatte hele skolers virksomhet, inkludert aktiviteter utover skoletid, ikke bare enkeltfag og klasser. Men etter innspill fra dem som takket ja, ble prosjektet noe nedskalert, og hvert enkelt land fikk noe større handlingsrom. ${ }^{19}$ Man samlet seg om at forsøkene tematisk skulle dreie seg om ett eller flere av de tre temaene kvinners rettigheter, andre land og kulturer, eller FN-systemet og FNs arbeid for menneskeretter og fred. Muligheter for sammenligning på tvers av land ble likevel understreket. Det forble derfor et krav at forsøkene skulle foregå på "secondary school level", og at forsøkene skulle gjøres til gjenstand for en evaluering i form av "objective tests of knowledge and attitude". ${ }^{20}$

I Norge var det den norske nasjonalkommisjonen for Unesco som mottok invitasjonen, og kalte sammen til et planleggingsmøte hvor representanter for så å si alle med interesse for den høyere skole ${ }^{21}$ var representert: Utdanningsrådet, Pedagogisk seminar, Lektorlaget, Kirke- og Utdanningsdepartementet, representanter fra ulike skoler, samt Pedagogisk Forskningsinstitutt. ${ }^{22}$ Det ble satt ned en forsøkskomite som skulle lede planleggingen og det videre arbeidet. Tre Oslo-skoler ble innlemmet $\mathrm{i}$ forsøkene: Fagerborg gymnas, Frogner skole og Oslo Katedralskole. ${ }^{23}$

Blant deltakerne kom det til uttrykk en klar forestilling om at det var viktig at Norge bidro, ja at prosjektets suksess kunne vise seg å være avhengig av norsk deltakelse. En av de deltakende lektorene, Finn Havnevik fra Oslo Katedralskole, hevdet at "saken er så viktig at jeg ikke synes vi skal ta noen sjanse på at forsøket mislykkes av

18 Unesco: Education for Living in a World Community: Co-ordinated Experimental Activities in Schools of Member States; General Preliminary Information, ED/127 (Unesco 1953).

19 Unesco (1965), 12-13; Teige (2011a), 185-86.

20 Referat, Komitéen for koordinerte forsök i skolen, Möte på Frogner skole, 22 august 1955, s. 2. (NKOM 1953-1955).

21 Den høyere skole (eg. Den høyere allmennskole) ble etter lov av 1935 en fellesbetegnelse på realskole og gymnas, som fulgte etter syvårig folkeskole. Fra 1964 gikk betegnelsen ut av bruk, som resultat av den nye folkeskoleloven av 1959. Denne åpnet for niårig enhetsskole, fulgt av treårig gymnas.

22 Report on the activities in Norway till January 1st 1955, rapport fra den norske nasjonalkommisjonen for Unesco til Unesco (NKOM 1953-1955); Teige (2011a), 187.

23 Når disse tre skolene fra et såpass snevert geografisk område ble valgt, var det delvis et uttrykk for hvor den skolepolitiske eliten befant seg, men hadde også med ressurser å gjøre. Overfor Utenriksdepartementet, beklaget Nasjonalkommisjonen i 1956 at ressurssituasjonen gjorde at "det har ikke vært mulig å drive nevneverdig virksomhet utover Oslo." (Stortingsmelding nr. 17 (1956), Om Norges deltakelse i De Forente Nasjoners Organisasjon for Undervisning, Vitenskap og Kultur (UNESCO)), 2. 
mangel på interesse og initiativ og oppfinnsomhet hos oss." ${ }^{24}$ Men det var også klare oppfatninger om at prosjektet var viktig i seg selv. Lektor Hans Mohr, også han fra Oslo Katedralskole, og rektor ved Asker gymnas Haakon Holmboe mente "det var på høy tid at det gjøres noe for å utnytte den muligheten vi har til gjennom skolen å oppdra den kommende generasjon til større internasjonal forståelse." ${ }^{25}$

Leder for forsøkskomiteen var altså Hakon Vigander, som også selv var deltaker som rektor på Frogner skole. Kirke- og utdanningsdepartementet (KUD) var representert ved ekspedisjonssjef for Skoleavdelingen Einar Boyesen. Det var hans departement som bevilget de nødvendige midler til førsøkene. Sammen med Utdanningsrådet var det også KUD som etter hvert godkjente de forslag til avvik fra læreplanene forsøkene krevde. ${ }^{26}$ Pedagogisk Forskningsinstitutt ved Universitetet i Oslo, var representert ved professor og bestyrer Johs. Sandven, som etter hvert også fikk ansvar for evalueringen.

Vigander og forsøkskomiteen gikk i gang med planlegging av forsøkene, og skoleåret 1955-56 ble det ved de tre skolene opprettet egne forsøksklasser. Disse fikk eget pensum og egne undervisningsopplegg i norsk, fransk, engelsk og historie, innrettet mot temaene menneskerettigheter og "kvinne-emansipasjonen". ${ }^{27} 1957$ kom Sandven med sin evaluering, hvor han mente å kunne dokumentere positive effekter av forsøksundervisningen, både i kunnskaper og holdninger, selv om resultatene ikke var helt entydige. ${ }^{28}$ En siste runde med forsøk ble foretatt i 1958-1959. Nå var også Asker gymnas og Stabekk skole med, og forsøkene ble denne gang ledet av lektor Josef Faaland fra Stabekk skole. Temaet var internasjonal forståelse. Denne runden av forsøk ble imidlertid "forfulgt av en rekke uhell", ${ }^{29}$ og utgivelsen av Tre års undervisningsforsøk etter UNESCO-tiltak i 1960, med engelsk utgave i 1962, oppsummerte forsøkene og markerte i praksis avslutningen på det norske engasjementet $\mathrm{i}$ prosjektet. ${ }^{30}$

\section{Kulturelle relasjoner mellom forestillinger og bilder}

Basert på studier av de nordiske og baltiske land på 1900-tallet, beskriver Clerc og Glover (2015) arbeidet for å bygge internasjonale, kulturelle relasjoner som en vekselvirkning mellom nasjonale selvforståelser og de bilder som finnes av nasjonen internasjonalt. Det er sentralt hvordan disse praksisene aktiverer forestillinger (imaginings) nasjoner har om seg selv, i samspill med de bilder (images) man mener finnes der ute og som nasjonene søker å skape, foredle eller motarbeide. ${ }^{31} \AA$ identifisere

24 Her sitert fra Teige (2011a), 186.

25 Ibid.

26 Faaland og Vigander (1960). Se også Den Høgre Skolen 1956, 660ff.

27 For en nærmere beskrivelse av forsøkene, se Den Høgre Skolen 1956, 660ff og 687ff; Faaland og Vigander (1960) og Teige (2011a), 187-99.

28 Sandven (1957a).

29 Faaland og Vigander 1960, 9.

30 Faaland og Vigander (1960); Josef Faaland og Haakon Vigander, Educational Experiments Carried Out Over a Three-Year Period Under a UNESCO Scheme (Oslo: Unesco and the Norwegian Government, 1962). I 1960 ble riktignok Eik Lærerskole med i ASPRO, men var den eneste norske institusjonen i nettverket frem til 1980-tallet, da den norske deltakelsen igjen fikk et oppsving.

31 Luis Clerc og Nikolas Glover "Representing Small States in Northern Europe: Between Imagined and Imaged Communities," i Histories of Public Diplomacy and Nation Branding in the Nordic and Baltic Countries: Representing the Periphery, red. Louis Clerc, Nikolas Glover og Paul Jordan. (Leiden/Boston: Brill Nijhoff, 2015), 6. 
slike forestillinger og bilder vil også stå sentralt i min analyse: Hvilke forestillinger og bilder lå til grunn for det norske arbeidet med å bygge kulturelle relasjoner og hvordan knyttet Unesco-fors $ø$ kene seg til disse?

Videre, identifiserer Clerc og Gloover (2015) et "small state tool kit" små stater har til rådighet for å gjøre seg gjeldende i ofte asymmetriske relasjoner overfor større land. ${ }^{32}$ Sentralt her er de særlige forutsetningene små nasjoner har for å samle seg om brede, konsensuelle forestillinger om sitt land, som man så arbeider for å projisere. Dette åpner for at enkeltindivider kan spille en særlig fremtredende rolle i disse praksisene, der de kan opptre, og ser seg selv, som helt uproblematiske talspersoner for nasjonen som helhet. En sentral type av slike enkeltaktører er såkalte "foreign relations entrepeneurs", det vil si kosmopolitiske individer med gode språklige ferdigheter, kunnskap om utenlandske samfunn og tilgang til relevante nettverk. ${ }^{33} \mathrm{I}$ forlengelsen av dette oppstår et utpreget samkvem mellom statlige og ikke-statlige aktører, som stadig befinner seg rundt samme bord og gjerne går inn og ut av roller og posisjoner.

Dette leder til spørsmål mer i retning av organisering og enkeltaktører, som også er viktig for å forstå en eventuell diffusjon av motiver mellom myndigheter og deltakere i forsøkene. Hvordan var Unesco-forsøkene rammet inn organisatorisk, og hvordan bidro enkeltaktører i dette arbeidet? Lå det i Unesco-forsøkene et potensiale til å bidra i satsingen på å bygge kulturelle relasjoner, og på hvilken måte?

Kildene til denne undersøkelsen er for det første å finne i arkivet etter den norske nasjonalkommisjonen for Unesco, hvor vi får et innblikk i hvilke institusjoner og aktører som var involvert og hvordan de samhandlet. ${ }^{34}$ Nasjonalkommisjonen hadde sekretærfunksjon for forsøkskomiteen, og møtereferater og korrespondanse er derfor bevart der. Jeg vil holde denne informasjonen opp mot tidligere forskning på arbeidet med kulturelle relasjoner i perioden. Til en viss grad vil også det materialet forsøksvirksomheten selv etterlot seg, i form av rapporter, pensumlister og undervisningsopplegg være av nytte. Her blir de to enkeltaktørene Haakon Vigander og Einar Boyesen viktig. Gjennom taler de holdt, tekster de skrev og debatter de deltok i og inngikk $\mathrm{i}$, får vi et bilde av deres forestillinger og motivasjoner for å delta i Unescoforsøkene, både som individer, men også som representanter for de institusjonene og organisasjonene de var en del av.

\section{Unesco-forsøkene og Kontoret for kulturelt samkvem med utlandet}

I 1950 vedtok det norske Stortinget å opprette Kontoret for kulturelt samkvem med utlandet (heretter Kontoret for kulturelt samkvem) som en avdeling under Utenriksdepartementet, med oppdrag om å forvalte Norges kulturelle relasjoner med andre land. Dette innebar både å drive rent kultursamarbeid og å gjøre Norge kjent $\mathrm{i}$

32 Ibid., 9-12.

33 Ibid., 9. Se også Kristine Kjærsgaard: "A Public Diplomacy Entrepreneur: Danish Ambassador Bodil Begtrup in Iceland, Switzerland and Portugal, 1949-1973," i Histories of Public Diplomacy and Nation Branding in the Nordic and Baltic Countries: Representing the Peripery (Leiden/Boston: Brill Nijhoff, 2015), 102-22.

34 Riksarkivet, Den norske Nasjonalkommisjonen for UNESCO, Serie Da, Saksarkiv, Eske 32, Mappe Skoleforsøkene generelt 1953-1955 (NKOM 1953-1955) og Mappe Skoleforsøkene generelt 1956-1959 (NKOM 1956-1959). Takk til Svein Ivar Angell, som har stilt dette kildematerialet til disposisjon for artikkelforfatteren. 
omverdenen. ${ }^{35}$ Opprettelsen av Kontoret for kulturelt samkvem var, som Unesco, et tidstypisk uttrykk for troen på kultur og opplysning som konfliktforebyggende elementer i internasjonalt samarbeid. Lignende institusjoner ble også satt opp i mange andre europeiske land på samme tid. ${ }^{36}$ Som et lite land, så Norge seg også tjent med et internasjonalt klima preget av samarbeid og lavt konfliktnivå.

Det som kjennetegnet det norske selvbildet i denne satsingen, var en forestilling om at det fantes en særegen norsk fredstradisjon, og at Norge var forpliktet til å spille en formidlende og fredsbyggende rolle på verdensscenen. ${ }^{37}$ Dette var forestillinger som strakk seg tilbake til begynnelsen av århundret, og er et typisk eksempel på den vekselvirkningen Clerc og Glover (2015) beskriver. Dette kom også tydelig til uttrykk i argumentasjonen for å opprette Kontoret for Kulturelt samkvem:

\begin{abstract}
Norges omdømme som kulturland er høyt. På en rekke felter - særlig i mellomkrigstiden - har vårt land befestet sitt ry for alltid å stå i forreste rekke i arbeidet med fredelige fremskritt. Ved internasjonale kongresser og på annen vis har Norge hyppig kunnet glede seg over at dets meninger har vært tillagt en betydning som er gått utover det folkets størrelse skulle tilsi. Departementet mener at dette omdømme forplikter til en rasjonell utbygging av vårt kulturelle samkvem med utlandet. ${ }^{38}$
\end{abstract}

Det ble særlig fremhevet at Norge kunne spille en slik rolle med utgangspunkt i et høyt utviklet utdanningssystem. ${ }^{39}$ Selv om Kontoret for kulturelt samkvem formelt sorterte under utenriksdepartementet, overtok derfor avdelingen en rekke oppgaver som tidligere hadde lagt under KUD, som dermed øvet stor innflytelse over arbeidet. Blant annet sto Kontoret for kulturelt samkvem for utgivelsen av tre bøker om det norske utdanningssystemet beregnet på et utenlandsk publikum, mellom 1955 og 1958. Einar Boyesen skrev forordet til den første av dem, mens de to andre ble skrevet av Olav Hove og Ingeborg Lycke, også de høytstående embedsmenn i KUD. ${ }^{40}$

Den norske nasjonalkommisjonen for Unesco ble også underlagt Kontoret for kulturelt samkvem. I tråd med Unescos konstitusjon, hadde Stortinget i 1946 opprettet en egen nasjonalkommisjon for Unesco. Den skulle tjene som rådgiver for regjeringen $\mathrm{i}$ Unesco-saker, som rådgiver for den norske delegasjonen til Unescos generalkonferanser og som bindeledd mellom Unesco og norske kulturorganisasjoner og

35 Angell (2014); Angell (2015).

36 Nikolas Glover, National Relations: Public Diplomacy, National Identity and the Swedish Institute 1945-1970 (Lund: Nordic Academic Press, 2011); Angell (2014).

37 Angell (2014).

38 Stortingsproposisjon nr. 1 (1950), 13. Se også Angell (2014).

39 Angell (2014); Angell (2015); Ragnhild Eitungjerde Høyvik, “Fram fra skjoldets skygge:” Norsk arbeid med kulturrelasjoner overfor utlandet 1945-1973 (Masteroppgave, Universitetet i Bergen 2014).

40 George M. Wiley, The Organisation and Administration of the Educational System of Norway (Oslo: Royal Norwegian Ministry of Foreign Affairs, Office for Cultural Relations and Royal Norwegian Ministry of Church and Education, 1955); Olav Hove, An Outline of Norwegian Education (Oslo: Royal Norwegian Ministry of Foreign Affairs, Office for Cultural Relations and Royal Norwegian Ministry of Church and Education, 1955 - nytt opplag i 1958); Ingeborg Lycke, Adult Education in Norway (Oslo: Royal Norwegian Ministry of Foreign Affairs, Office for Cultural Relations, 1957); Svein Ivar Angell, "The Result of Gradual Development of Democratic Idealism:" Education and Images of Norway in the Post-War Period, forthcoming. 
institusjoner. ${ }^{41}$ De første årene eksisterte det ingen egen bevilgning til denne kommisjonen, bortsett fra et mindre beløp fra KUD. Men fra 1950 fikk nasjonalkommisjonen sin egen bevilgning av budsjettet til Kontoret for kulturelt samkvem. Fra 1952 fikk den fikk sitt eget sekretariat, og bevilgningene økte jevnt utover på 1950-tallet. ${ }^{42}$ Finansieringen av Unesco-forsøkene kom likevel direkte fra KUD, ekspedert av Einar Boyesen. ${ }^{43}$

Slik lå de organisatoriske rammene til rette for at Unesco-forsøkene skulle innlemmes i det norske arbeidet for å bygge kulturelle relasjoner. Nasjonalkommisjonens arbeid vekslet da også mellom på den ene siden å gjøre Unescos virksomhet kjent i Norge, på den andre siden å gjøre Norge synlig på mange ulike felt overfor Unesco og de nasjonene som befant seg der. Nasjonalkommisjonen var slik en bidragsyter når det gjaldt å promotere norsk kultur og samfunnsliv internasjonalt. En ikke ubetydelig del av kommisjonens ressurser gikk også med til å møte en stor interesse for norsk skole og utdanning, og kommisjonen mottok hvert år en rekke forespørsler fra Unesco om undervisningsspørsmål i Norge. ${ }^{44}$ KUD var en viktig bidragsyter i dette arbeidet. ${ }^{45}$ Det er grunn til tro at Unesco fra starten også anså Norge som en viktig samarbeidspartner i Unesco-forsøkene. ${ }^{46}$

Det mest sentrale ansvarsområdet for Kontoret for kulturelt samkvem, var de første årene å forvalte utvekslingsavtaler innen høyere utdanning. Stipender ble delt ut til studenter fra andre land som ønsket å studere i Norge, og til norske studenter som ønsket å studere i utlandet. Utvekslingsavtalene var en kanal norske myndigheter for det første brukte aktivt for å skape et positivt bilde av Norge i utlandet, der det var et uttalt mål å gi støtte til studenter man anså særlig skikket til å gi et positivt bilde av Norge i hjemlandet. ${ }^{47}$ For det andre var det en kanal for å styrke internasjonaliseringen av norsk forskning og høyere utdanning, særlig overfor Storbritannia og USA. ${ }^{48}$ Det var også mot USA at de fleste utvekslingsavtalene var innrettet. Det eksisterte klare forestillinger i Norge om at Norge politisk og kulturelt var særlig kompatible med de liberal-demokratiske verdier USA representerte, og at Norge derfor kunne og burde være en medspiller i å utvikle et slikt politisk prosjekt. Disse liberal-

41 Stortingsmelding nr. 17 (1956), Om Norges deltakelse i De Forente Nasjoners Organisasjon for Undervisning, Vitenskap og Kultur (UNESCO), 1-2.

42 St. meld. nr. 17 (1956), 2; St. meld nr. 78 (1956): Om virksomheten ved Kontoret for kulturelt samkvem med utlandet 1. juli 1950-30. juni 1956., 6-7.

43 Brev fra Det kongelige Kirke- og Undervisningsdepartement, Skoleavdelingen, til Den norske nasjonalkommisjonen for Unesco v/rektor Haakon Vigander, Oslo 11. februar 1957, Forsøk i skolen etter Unesco-planen (NKOM 1956-1959). Departementet bevilget her kr. 3000,- til "forstsatte fors $ø \mathrm{k}$ [...] etter Unescos plan." Brevet var signert Rolf Bergmann, "for ekspedisjonssjefen". Bergmann var som byråsjef $\mathrm{i}$ skoleavdelingen like under Boyesen i departementshierarkiet. Bergmann deltok også på møtene i forsøkskomiteen frem til de ble satt i gang i 1955. (Referat, Den norske Nasjonalkommisjonen for Unesco - Komitéen for koordinerte forsök i skolen, Møte på Frogner skole 22. august 1955 (NKOM 1953-1955)).

44 St. meld. 17 (1956), 4.

45 Den norske nasjonalkommisjonen for Unesco: Oversikt over virksomheten i tidsrommet 1. november 1953 - 15. april 1955, side 4. (NKOM) Blant annet ble kommisjonen bedt om å bidra til et oppslagsverk over ord og uttrykk som ble brukt i undervisning. KUD utarbeidet den norske delen av verket.

46 Teige (2011a), 186.

47 Angell (2014), 28; Angell (2015), 89.

48 Angell (2014); Angell (2015); Høyvik (2014). 
demokratiske verdiene hadde også sterk innflytelse i Unesco, og det har blitt hevdet at Unesco i sine innledende år var en "disseminator of liberal-democratic ideas of [...] Anglo-American origin." ${ }^{49}$

I tråd med dette foregikk det i etterkrigstiden også en reorientering av norsk forskning fra franske og tyske tradisjoner mot en anglo-amerikansk tradisjon..$^{50}$ Dette skiftet kom også til uttrykk ved ansettelsen av Johs. Sandven som bestyrer for Pedagogisk forskningsinstitutt i 1950. Han representerte en sterkt amerikanskorientert, test-psykologisk tradisjon, og erstattet Helga Eng, som hadde vært langt mer europeisk orientert. ${ }^{51}$

Unesco-forsøkenes kobling mellom skole, forskning og internasjonal orientering passet derfor godt både med de forestillinger og bilder som lå til grunn for norsk kultursamarbeid i disse årene, og den innretning arbeidet i praksis hadde. I tråd med Kontoret for Kulturelt samkvems viktigste portefølje, finansierte også Unesco utvekslingsstipender for aktive deltakere i Unesco-forsøkene, noe Norge benyttet seg $a v .{ }^{52}$ I 1955 reiste nevnte Finn Havnevik til Unesco House i Paris, hvor han fikk lære om Unesco, besøke deltakende skoler, treffe stipendiater fra andre land, og ble selv bedt om å presentere de norske forsøkene. ${ }^{53}$ Etter forespørsel fra Unesco, tok Norge samme år imot fire lærere involvert i prosjektet fra Japan, Colombia, Sveits og Frankrike. ${ }^{54}$ Det er illustrerende å se den nære samhandlingen mellom institusjoner og aktører som kom til uttrykk ved dette besøket.

Både Kontoret for kulturelt samkvem, KUD, forsøkskomiteen og nasjonalkommisjonen var alle aktivt involvert i mottakelsen. Det var Haakon Vigander som hadde mottatt forespørselen fra Unesco, og spurte Kontoret for kulturelt samkvem om bistand: "Formannen [Haakon Vigander] hadde snakket med Utenriksdepartementets Kulturkontor som ville hjelpe til med programmet under oppholdet i samarbeid med Kirke og Undervisningsdepartementet ved byråsjef Hove." ${ }^{55}$. Sekretæren for forsøkskomiteen og nasjonalkommisjonen, Liv Hennum, responderte på forespørselen:

[T] he Office of Cultural Relations of the Ministry of Foreign Affairs, the Ministry of Ecclesiastical Affairs and Education, and the Committee of the National Commission dealing with the Co-ordinated Experimental Activities will do their best to make the visit of the Fellows in Norway as interesting and profitable as possible. ${ }^{56}$

49 F.W. Thue, In Quest of a Democratic Social Order: The Americanization of Norwegian Social Scholarship 1918-1970 (Oslo: University of Oslo, 2005), sitert fra Angell (2015), 89.

50 Thue (2005); Angell (2015).

51 Kim Helsvig, Reform og rutine: Kunnskapsdepartementets historie 1945-2017 (Oslo: Pax, 2017), 63, $127 \mathrm{ff}$.

52 Fellowships for Travel and Study, Brev fra Unesco Education for International Understanding and Cooperation, Co-ordinated Experimental Activities in Schools of Member States til deltakerlandene, Paris 19 juli 1954, UNESCO/WS/064.93. (NKOM 1953-1955).

53 Brev fra Unesco til Finn Havnevik, 22. juli 1955 (NKOM 1953-1955).

54 Co-ordinated experimental activities in schools of menber states. Report from Norway - November 1955 (NKOM 1953-1955).

55 Referat, Komitéen for koordinerte forsõk i skolen, Möte på Frogner skole, 22. august 1955 (NKOM 1953-1955).

56 Brev fra Liv Hennum, sekretær for den norske nasjonalkomiteen til William D Carter, Head, Exchange of Persons Service, Unesco, 17 August 1955 (Hennum-Carter 1955: NKOM 1953-1955) 
Gjestene skulle få besøke forsøksskoler og diskutere med lærerne der, og Hennum foreslo å arrangere møter med "leading personalities in education." ${ }^{57}$ Mottakelsen ble holdt som en lunsj på Presseklubben i Oslo, med kanapeer, wienerschnitzel, rødvin og is. ${ }^{58}$ Forsøkskomiteen var representert ved Hennum, Vigander og tre lektorer fra deltakende skoler, ${ }^{59}$ mens KUD og skoleavdelingen var representert ved byråsjef Rolf Bergmann. Kontoret for kulturelt samkvem tok regningen. ${ }^{60}$

Unescos vekt på at forsøkene skulle være av vitenskapelig karakter, gjenspeilte dessuten et sentralt trekk ved norsk skolepolitikk på denne tiden, nemlig troen på at den den fremvoksende pedagogiske vitenskapen skulle vise vei i skoleutviklingen. Einar Boyesen sto som eksponent for dette. ${ }^{61}$ Noe av det første han gjorde etter han tiltrådde stillingen som ekspedisjonssjef i 1938, var å delta i komiteen som utarbeidet den første studieplanen for det da nyopprettede Pedagogiske Forskningsinstitutt (PFI). Her arbeidet han også som sensor og holdt forelesninger i pedagogisk historie gjennom hele sin tid som ekspedisjonssjef. ${ }^{62}$ PFI sto således Boyesens hjerte nær, og var tiltenkt en fremskutt posisjon i norsk skoleutvikling. Når Johs Sandven fikk oppgaven med å ivareta prosjektets vitenskapelige profil gjennom en evaluering, var dette derfor ikke bare et uttrykk for at Norge var villig til å bruke sine mest fremstående ressurser på prosjektet. Det var vel så mye en mulighet for å projisere et bilde av norsk skole som moderne og forskningsbasert, noe man innenfor rammen av Unesco-forsøkene hadde all grunn til å tro at ville resonnere godt. Slik var Unesco-forsøkene ikke bare en arena for projisering av den norske skolen som særlig egnet til å bygge fred og internasjonal forståelse, men vel så mye en arena for promotering av norsk pedagogisk vitenskap i seg selv.

Det er imidlertid interessant at Sandven til å begynne med ikke ønsket at verken han selv eller PFI "som sådann" skulle være ansvarlig for evalueringen. ${ }^{63}$ På et møte i forsøkskomiteen i 1955, uttrykte han bekymring for at det kunne bli kostbart og ta mye tid, takket nei, og foreslo at heller "en moden student i siste fase av sitt studium kunne gjöre det", eller "en av de deltakende lærere [...], enten alene eller i samarbeid med en student." ${ }^{64}$ Ingen av de deltakende lærerne, som alle var til stede på møtet, meldte sin interesse, og Haakon Viganders respons var at man fikk søke departementet om midler. Sandven fikk ansvaret for å avklare hvem som skulle gjennomføre evalueringen "innen 4. oktober", en drøy måned etter møtet fant sted.

Det er et åpent spørsmål hvordan det siden gikk til at Sandven selv utførte oppdraget. Som fagmann og forsker innenfor en tradisjon med sterkt objektive idealer, er det ikke til å undres over at han kan ha følt seg beklemt av den utpreget normativtpolitiske målsettingen bak Unesco-forsøkene, og det nasjonale markeringsbehovet

57 Hennum-Carter 1955.

58 Brev fra Liv Hennum til Presseklubben, 22. november 1955 (NKOM 1953-1955). Vedlagt brevet var også bordkart, meny, bestilling av Unesco-bordkort og lys på bordet.

59 Dette var Hans Mohr og Finn Havnevik fra Oslo Katedralskole, og Alf Kinge fra Fagerborg skole. Kinge var for øvrig også formann i Internasjonal vennskapsliga og medlem i Norges Fredsråd.

60 Brev Liv Hennum til Presseklubben, 22. november 1955 (NKOM 1953-1955).

61 Helsvig (2017), 53ff.

62 Ibid.

63 Referat, Komitéen for koordinerte forsõk i skolen, Möte på Frogner skole, 22. august 1955 (NKOM 1953-1955).

64 Referat møte Frogner skole 1955. 
som omgav dem. Gjennom hele sin tid som leder av PFI markerte Sandven seg også i ulike sammenhenger som motstander av en politisert skoleforskning. ${ }^{65}$ Men som amerikanskorientert representant for norsk høyere utdanning og skoleutvikling, finansiert av de facto de samme myndigheter som nå ba ham gjøre evalueringen, sto han sentralt i denne satsingen, enten han ville eller ikke. Dessuten, som leder for Norges fremste pedagogiske forskningsmiljø, var heller ikke verdien av å gjøre denne forskningen internasjonalt kjent, fremmed for ham. Samme år som Sandven publiserte sin evaluering i Scandinavian Journal of Educational Reserach (1957), skrev han også en artikkel i International Review of Education, med tittelen Educational Research in Norway. The Development since $1950 .{ }^{66}$ Dette var i realiteten en smørbrødliste over tilsynelatende alle norske pedagogiske forskningsprosjekter og forskere i perioden. ${ }^{67}$

\section{Haakon Vigander som "foreign relations entrepeneur"}

Det var ikke bare sitt "ry" Norge hadde å legge på bordet overfor Unesco. Som ambassadør for foreningen Nordens lærebokrevisjoner i Unesco-apparatet hadde Haakon Vigander frem mot 1953 opparbeidet seg en særlig posisjon innenfor organisasjonens utdanningsrettede arbeid.

Haakon Vigander var lektor i tysk, engelsk og historie og arbeidet etter krigen som rektor på Frogner skole. Han hadde da lang fartstid i nasjonale og internasjonale fora som var opptatt av historie, skole og internasjonalt, konfliktforebyggende arbeid. ${ }^{68}$ Når man ved opprettelsen av Kontoret for kulturelt samkvem snakket om "mellomkrigstiden" og "internasjonale kongresser", er det ikke usannsynlig at historikerorganisasjonen International Comittee of Historical Scienses (ICHS) sin første generalkonferanse i Oslo i 1928 en av dem man hadde i tankene. ICHS arbeidet for en mer internasjonalistisk orientert historieforskning og -undervisning, og ble stiftet i Geneve i 1926. Den norske historikeren og senere utenriksministeren Halvdan Koht ble valgt til komiteens første president, og som sekretær på konferansen, holdt i "the spirit of Oslo", virket Haakon Vigander. ${ }^{69}$

Sammen med Koht, spilte Vigander også en sentral rolle i Foreningen Nordens lærebokrevisjoner, der han blant annet hadde ledet den den norske granskingskomiteen. I tråd med diskursen om kultursamarbeid internasjonalt, foretok de nordiske land på eget initiativ i mellomkrigstiden flere omfattende, gjensidige granskinger av lærebøker, hovedsakelig i historie, for å bygge ned konfliktfremmende perspektiver og formuleringer. ${ }^{70}$ Det man hadde fătt til i Norden var, mente man, verdifullt, særlig ved at det hadde gitt konkrete og merkbare resultater. Dette sto i kontrast til det Folkeforbundet og mylderet av andre velmenende initiativer hadde oppnådd, der arbeidet for det meste hadde kokt bort i konferanser, resolusjoner og seminarer. Denne

65 Helsvig (2017), 123ff.

66 Johs. Sandven, “Educational Research in Norway: The Development since 1950," International Review of Education 3, no. 3 (1957b), 373-77.

67 Evalueringen av Unesco-forsøkene var også nevnt.

68 Brit Marie Hovland, Historie som skolefag og dannelsesprosjekt 1889-1940: En historiografi ut fra folkeskolens historieloerebøker (Oslo: Universitetet i Oslo 2016).

69 Hovland (2016), 171.

70 Henrik Åström Elmersjö, Norden, nationen och historien: Perspektiv på föreningarna Nordens historieläroboksrevision 1919-1972 (Lund: Nordic Academic Press, 2013). 
selvforståelsen kom klart til uttrykk hos Haakon Vigander. I et foredrag han i 1946 holdt i alle fall ved to anledninger, ${ }^{71}$ presenterte Vigander et narrativ hvor Folkeforbundet, "som i år endelig skal gravlegges", og nærmest alle andre bestrebelser på feltet hadde mislyktes. Han beskrev dem som

[...] en broket skare av fredsvenner, moralister, kirkefolk, folkeforbundsfolk, historielærere og historiegranskere som med hverandre, om hverandre og på siden av hverandre samlet lærebøker og rapporter om lærebøker, vedtok ønskemål og reformforslag, mens Institutt for intellektuelt samvirke i Paris trykte bøker om alt som var sagt og planlagt på alle møtene. ${ }^{72}$

Mot dette sto foreningen Norden:

Denne alminnelige opptatthet i mellomkrigstiden av en historieundervisning i folkeforsonende ånd, gjorde seg også gjeldende i våre nordiske land, og her nådde arbeidet ganske andre positive resultater enn annetsteds. [...] [E]rfaringene fra det nordiske samarbeide [...] tror jeg vil kunne få betydning for det fremtidige arbeidet også mellom andre land..$^{73}$

Allerede i mellomkrigstiden hadde foreningen Norden forsøkt å gjøre sitt arbeid internasjonalt kjent. Motivasjonen var i hovedsak et ønske om å sette Norden på kartet, gjennom å vise frem noe man mente var unikt i verdenssammenheng. Som Henrik Elmersjö skriver, var målet ikke å spre den nordiske tanken i og for seg, men snarere å "visa upp sitt fredliga hörn av verden, att gå före og visa hur större förståelse för varandras historiea kunde leda till vännskapligare relationer." ${ }^{74}$ Det viste seg imidlertid vanskelig å vinne anerkjennelse for arbeidet internasjonalt, og bestrebelsene forble uten hell. ${ }^{75}$

Men dette endret seg etter andre verdenskrig. Da Unesco gjenopptok det arbeidet som hadde myldret i mellomkrigstiden, var det en viktig målsetting å bli nettopp den samlende kraft som Vigander påpekte mangelen av. Å få en plan i arbeidet ble nå fremtredende, for at det ikke igjen skulle smuldre opp i gode intensjoner. Blant annet startet man forberedelsene til å skrive "A history of Mankind", som var ment å skulle fungere som et referanseverk for alle verdens lærebokforfattere. ${ }^{76}$ I 1949 gav Unesco også ut en håndbok i lærebokrevisjon. ${ }^{77} \mathrm{I}$ denne fikk foreningen Norden høyeste karakter: "the accomplishments of the organization provide the most outstanding example so far of regional collaboration on textbook revision." ${ }^{78}$

71 En gang for Norsk gruppe av Internasjonal kvinneliga i Oslo i februar, og i august på et seminar for norske og britiske lærere i Hundorp.

72 Haakon Vigander, Historieundervisningen og mellomfolkelig forståelse: Foredrag holdt i Nobelsalen, Oslo, den 28. februar 1946 (Oslo: Norsk gruppe av internasjonal kvinneliga for fred, 1946a), 7-8.

73 Vigander (1946a), 9-10.

74 Elmersjö (2013), 109-10.

75 Ibid.

76 Sæle (2013), 55-56.

77 UNESCO, A Handbook for the Improvement of Textbooks and Teaching Materials: As Aids to International Understanding (Paris: Unesco, 1949); Sæle (2013), 51-58.

78 UNESCO (1949), 34. 
Året etter gav Unesco ut heftet Mutual Revision of History Textbooks in the Nordic Countries (herfra Mutual Revision), skrevet av Vigander. ${ }^{79}$ Denne vant mye gehør, og Vigander og de nordiske bestrebelsene ble i årene som fulgte flere ganger trukket frem som eksempler til etterfølgelse. Det er ingen overdrivelse å si at Viganders utgivelse i stor grad ble retningsgivende for Unescos arbeid på feltet i årene som fulgte. Mutual Revision fungerte som arbeidsdokument for flere større Unesco-seminarer i 1950 og 1953, hvor Vigander også deltok som seminarleder. ${ }^{80}$ Vigander personlig vant dermed også et navn, og ble stadig nevnt i ulike Unesco-rapporter der lærebokrevisjon var omtalt. I Unesco-avisen "The UNESCO Courier" ble han endatil omtalt som professor, selv om dette ikke var tilfellet. ${ }^{81}$ Slik var det Vigander personlig som ble eksponent for foreningen Nordens arbeid internasjonalt.

Også sentrale aktører som den tyske historieprofessoren Georg Eckert, lot seg inspirere av Vigander, og oppmuntret ham til å bringe foreningen Nordens lærebokarbeid videre ut over Nordens grenser. Georg Eckert var grunnleggeren av "Georg Eckert Institut für Internationale Schulbuchverbesserung" (senere Schulbuchforschung) i Braunschweig, som sammen med Europarådet førte det internasjonale lærebokarbeidet videre etter at Unesco trappet ned sitt engasjement i $1953 .{ }^{82}$ Vigander og foreningen Norden var en viktig inspirasjonskilde for dette arbeidet, ${ }^{83}$ og Vigander arbeidet også senere med fremstillingen av norsk-tyske forhold i tyske lærebøker. ${ }^{84}$

Den posisjonen Vigander hadde oppnådd i dette miljøet, gjorde ham godt rustet til å opptre som det Clarc og Gloover kaller en "foreign relations entrepeneur". Som lektor i engelsk og tysk, hadde han gode språkkunnskaper i sentrale språk, og hadde opparbeidet seg en status i Unesco-nettverket som gjorde at han ble lyttet til. Slik var Norge ved opprettelsen av Unesco-forsøkene godt rustet til å nøre oppunder og holde frem det norske selvbildet som foregangsnasjon i fredssaken. Samtidig resonnerte det godt med Kontoret for kulturelt samkvems satsing på å spre kunnskap om det norske skolevesenet og norsk utdanning.

\section{Einar Boyesen}

Einar Boyesen fungerte i denne sammenhengen som det mest fremtredende bindeleddet mellom foreningen Nordens arbeid for mellomfolkelig forståelse, norsk skolepolitikk, det norske arbeidet for å bygge kulturelle relasjoner, og Unesco-forsøkene. Det var han og hans avdeling i KUD som finansierte forsøkene, var aktive bidragsytere for Kontoret for Kulturelt samkvem og hadde ansvaret for norsk skolepolitikk. Boyesen hadde også lang fartstid sammen med Koht og Vigander i foreningen

79 Haakon Vigander, Mutual Revision of History Textbooks in the Nordic Countries (Paris: Unesco, 1950). Denne kom også ut på fransk og tysk.

80 UNESCO, Better History Textbooks (Paris: Unesco, 1951); UNESCO: Bilateral Consultations for the Improvement of Textbooks (Paris: Unesco, 1953).

81 "Experts Study History Textbook Improvement for Unesco Programme”, UNESCO Courier, vol. III, nr. 10, 24. Oktober 1950, 11. Vigander ble her presentert som "Professor of English and History, Oslo College."

82 Sæle (2013)

83 Georg Eckert, "Internationale Schulbuchrevision," Internationale Schulbuchforschung, no. 6 (1960), 399-415.

84 Haakon Vigander, "Deutsche Lehrbücher und die Darstellung der deutsch-norwegischen Beziehungen im Zweiten Weltkrieg," Internationales Jahrbuch für Geschichtsunterricht 8 (1961), 276-79. 
Norden. Det Hovland (2018) omtaler som "trespannet Koht, Vigander og Boyesen" utgjorde i tiden før og etter andre verdenskrig en skolepolitisk elite i Norge, og i flere sammenhenger også internasjonalt, der de satt "på alle sider av bordet" og øvde stor innflytelse både over historieforskningen, historieundervisningen, skolen i sin alminnelighet og i det politiske liv. ${ }^{85}$ Der Koht ble utenriksminister i 1935, fikk Boyesen som nevnt stillingen som ekspedisjonssjef for skoleavdelingen i Kirke- og Utdanningsdepartementet i 1938. Og han tok perspektivene fra foreningen Norden med seg inn dit. Som eneste nordiske land, ble det fra 1938 et krav om at alle godkjente lærebøker i historie skulle ha gått igjennom foreningens revisjoner. ${ }^{86}$

Boyesen var, sammen med Haakon Vigander, også før etableringen av Kontoret for kulturelt samkvem engasjert i arbeidet med å promotere Norge gjennom å holde frem utdanningssystemet. Utviklingen av sterke kulturelle bånd til Storbritannina, var høyt prioritert av norske myndigheter under den tyske okkupasjonen, og Utenriksdepartementet promoterte norsk samfunnsliv i en rekke bøker og pamfletter med hensikt å opplyse britene om norsk historie, litteratur og institusjoner. ${ }^{87}$ I tråd med dette arrangerte KUD med Einar Boyesen i spissen en konferanse for norske og britiske lærere på vikingegården Hundorp i Gudbrandsdalen i 1946. Boyesen hold her åpningstalen, samt et foredrag hvor han snakket varmt om det norske utdanningssystemet, mens Vigander fremførte sitt nevnte foredrag om historieundervisning og internasjonal forståelse. ${ }^{88}$

Når det gjelder Boyesen og Unesco-forsøkene, gav han uttrykk for de samme forestillingene Vigander hadde gitt uttrykk for når det gjaldt lærebokrevisjon: Unesco ville trenge hjelp fra Norden om prosjektet skulle føre noen vei. Dette kom tydelig til uttrykk på det femte nordiske undervisningsministermøtet i København i februar 1954, hvor Boyesen tok initiativet til et ordskifte om forsøkene, og luftet muligheten for et nordisk samarbeid. Norge var da det landet som hadde kommet lengst i forberedelsene, og som gikk mest omfattende til verks med tre deltakende skoler. Sverige planla å delta med en skole, mens man fra dansk side nylig var blitt orientert om saken. ${ }^{89}$

Boyesen inntok på dette møtet en temmelig paradoksal posisjon, hvor han på den ene siden nærmest dømte Unesco-forsøkene nord og ned, samtidig som han ønsket å satse på dem. Hele prosjektet med Unesco-forsøkene ble sterkt kritisert, nærmest latterliggjort, fra dansk og norsk side. Slik det ofte var med Unesco, ifølge Boysen, savnet også Unesco-forsøkene et "nøgternt indhold". ${ }^{90}$ Hele ideen om "påvirke elevernes sindelag og sligt" smakte dessuten av propaganda, som norske og danske elever

$\overline{85 \text { Hovland (2018), } 115 .}$

86 Elmersjö (2013), 110-11.

87 Angell (2015), 82.

88 Einar Boyesen, "Norway's Educational System," i A Record of the Hundorp Conference for British and Norwegian Teachers, August 1946 (Oslo: Gyldendal, 1948), 9-25; Haakon Vigander: "The Teaching of History and International Understanding," i A Record of the Hundorp Conference for British and Norwegian Teachers, August 1946 (Oslo: Gyldendal, 1948), 79-118.

89 Det 5. nordiske undervisningsministermøde i København 7-10. februar 1954, Dagsordenens punkt 2: Co-ordinated Experimental Activities in Schools of Member States of Unesco (København: J. H. Sschultz, 1954), 83-90. Det var kun de skandinaviske landene som uttalte seg om saken. Den svenske skolen var Arvika skole.

90 Ibid., 89. 
ville reagere sterkt på. ${ }^{91}$ Også selve hovedformålet med forsøkene, å utvikle en egen type fredsundervisning, høstet kritikk av Boyesen: "Det forekommer meg at oppdragelse til internasjonal forståelse og internasjonalt samarbeid ikke nødvendigvis må kreve særskilt undervisningsstoff og særskilte undervisningstimer".92

Det var i det hele tatt "ikke i samme grad trang til et sådant forslag indenfor vore egne rækker", ifølge Boyesen, fordi internasjonal forståelse, mellomfolkelig samarbeid, fredssaken og menneskerettighetserklæringen allerede hadde gjennomsyret nordiske lands skolelovgivning og undervisningsplaner i mange år. ${ }^{93}$ Dessuten, ble det påpekt, hadde små nasjoner som de nordiske den fordel at de stadig måtte forholde seg til omverden på en helt annen måte enn større nasjoner. Internasjonalt samarbeid falt Norden derfor mer naturlig. Bare tanken på at Unesco eller noen andre skulle vise Norden vei på dette feltet var nesten uhørt. Fra Danmark ble det formulert slik:" jeg tror ikke, at vi har brug for en ekspert fra UNESCO til at komme ned å vise os, hvordan vi skal undervise i menneskerettighederne, det tror jeg, vi forstår lige så godt som han". ${ }^{4}$

Likevel var altså Boyesen blant pådriverne for den i nordisk sammenheng mest omfattende satsingen på Unesco-forsøkene, og også talsmann for felles-nordisk innsats. Øyensynlig ikke fordi han trodde på prosjektet i seg selv, men fordi Norden hadde "de bedste betingelser" til å bidra, "på grund af de hovedsynspunkter, som har behersket vore lande gennem lange tider". ${ }^{95}$ Dette gjorde Norden nærmest forpliktet til å vise vei i denne type initiativer, hvor klossete de enn måtte være.

På tross av at Danmark mildest talt stilte seg kjølig, mente de det var "rimelig å samles om en norsk tanke, idet det vitterlig er Norge, der indenfor UNESCO har været stadkolonnen på det kulturelle området." ${ }^{\prime 6}$ Det hele kunne dessuten løses veldig enkelt i Danmark, ved å plassere forsøkene innenfor rammene av gymnasiets "spesialer", frie emner hvor man sto fritt til å lage egne opplegg. Sverige var ikke like krass i uttalelsene som Norge og Danmark, men betraktet Unesco-fors økene for bare å være en liten del av den forsøksvirksomheten som allerede var i gang, og som i mangt allerede rettet seg mot de samme målsettinger som Unesco tegnet opp. Det var derfor viktig at Unesco-forsøkene i seg selv ikke tok for stor plass, og den svenske representanten advarte mot at dette kunne føre til en forsøkstretthet i skolen. De motsatte seg heller ikke muligheten for et samarbeid, men understreket at de i denne omgang ikke var ønskelig å utvide forsøkene.

Sverige og Danmark holdt slik Unesco-forsøkene noe mer på avstand enn Norge, ved å i større grad innlemme dem i strukturer som allerede fantes. På tross av at Boyesen verken mente det var behov for et slik prosjekt i Norden eller at et slikt prosjekt i det hele tatt var veien å gå for andre land heller, er det er interessant at Norge gikk såpass aktivt inn, og i stort fulgte de anvisninger Unescos hadde satt opp. Boyesen var åpenbart mer villig enn sine nordiske kolleger til så å si å stille norsk skole, norske lærere og norske elever til disposisjon for Unescos eksperiment, som henholdsvis

91 Ibid.

92 Ibid., 85.

93 Ibid., 88.

94 Ibid., 87.

95 Ibid., 88.

96 Ibid., 89 . 
laboratorium, forskere og forsøkskaniner, der Danmark og Sverige så et større behov for å trekke i bremsen. ${ }^{97}$ Samtidig gjenspeiler dette hvordan arbeidet med å bygge kulturelle relasjoner var institusjonelt forankret på ulike måter. Når særlig Sverige var såpass avmålt, kan det også ha sammenheng med at deres tilnærming var annerledes innrettet enn den norske. Mens den norske moderniseringsdiskursen siden starten av 1900-tallet hadde vært dominert av demokratiske og politiske verdier, hadde den svenske vært mer karakterisert av økonomiske og teknologiske verdier. Kontoret for Kulturelt samkvems svenske motsats, Det svenske Instiut, var et halvoffentlig organ hvor næringslivet var sterkt representert, og således mer innrettet mot å fremme næringslivsinteresser enn man var i Norge, der staten inntok en mer sentral posisjon. ${ }^{98}$

Fra medlemmene i den norske forsøkskomiteen fremkommer det også at man hadde kontakt med sine nordiske kolleger om prosjektet. Rektor ved Arvika skole, Arthur Inglander, fikk av Haakon Holmboe ros for å "fra første stund vært meget aktiv for å sette disse eksperimentene ut i livet", og også for sin innsats som seminarleder for et større Unesco-seminar om forsøkene i Hamburg i 1956. ${ }^{99}$ Til den den norske forsøkskomiteen kom det også inn en dansk bekymring for at de testene Unesco hadde satt opp ikke ville passe i de nordiske land. Vigander foreslo da at man burde rådføre seg med Inglander "for å undersöke hva han hadde gjort med hensyn til evaluering, og for eventuelt å få låne hans materiale." ${ }^{100}$

Det er likevel ingenting som tyder på at dette samarbeidet på noe tidspunkt ble formalisert eller koordinert, utover en mer sporadisk kontakt. Dette må nok sees i lys av at forsøkene gikk over relativt kort tid, der man hadde mange praktiske utfordringer å hanskes med, og synes å ha hatt nok med å tilpasse forsøkene eget skoleverk. På mange måter kom heller ikke det norske prosjektet lenger enn i prøvefasen, og man trakk seg ut relativt tidlig.

\section{Hvordan gikk det?}

Det er vanskelig å slå fast hvilken "impact" den norske innsatsen i Unesco-forsøkene fikk. Dette er heller ikke noe mål for denne artikkelen. Det kan likevel være interessant å dvele litt ved dette, fordi det bidrar til å kaste lys over hvorfor Norge trakk seg ut av et prosjekt som utover på 1960-tallet og videre var i sterk vekst. I Unescos egne rapporter og oppsummeringer av prosjektet ble Norges innsats omtalt i positive ordelag. ${ }^{101}$ Særlig ble norske myndigheters aktive tilrettelegging fremhevet som forbilledlig. ${ }^{102}$ Det er likevel ikke grunn til å hevde at Norge utpekte seg nevneverdig

97 Se Angell (2015) s. 85; Glover (2011); Svein Ivar Angell, Den svenske modellen og det norske systemet: tilhøvet mellom modernisering og identitetsdanning i Sverige og Noreg ved overgangen til det 20. hundreåret. (Oslo: Samlaget, 2002), 325-33.

98 Angell (2014); Angell (2015).

99 Haakon Holmboe, "Unesco-forsøk i skolen," i Norsk skole - Opplysnings og kunngjøringsblad for skoleverket, 3, no. 11 (1957), 163-67.

100 Referat, Komitéen for koordinerte forsõk i skolen, Möte på Frogner skole, 22. august 1955 (NKOM 1953-1955), s. 3.

101 Unesco Associated Schools Project in Education for International Understandig. Report on experimental projects carried out in Norwegian Secondary Schools, 1954-1956, Paris 16 April 1958, WS/038.87 (Unescodoc)

102 Co-ordinated experimental activities in education for international understanding and cooperation: interim report; activities in 1955 and 1956 (Unesco 1956), 10. ED/149 
i Unescos rapporter i forhold til andre land. Det ser heller ikke ut til at de særlige småstatsfordelene man mente å ha, i særlig grad slo til. Den gode følelsen av å ha "vært tillagt en betydning [...] utover det folkets størrelse skulle tilsi", som var en viktig motivasjon bak de norske bestrebelsene på å bygge kulturelle relasjoner i sin alminnelighet, gjorde seg derfor til syvende og sist knapt gjeldende i tilfellet med Unesco-forsøkene. Land som Frankrike og Tyskland, hvor volumet i virksomheten var større, fikk tilsvarende mer omtale enn Norge og andre mindre nasjoner, og Unesco synes å ha vært minst like interessert i hva som hadde foregått der.

Likevel fikk Norge utvilsomt markert seg som en medspiller til Unesco, og vist at man var villig til å stille opp for de verdier organisasjonen representerte. Men det synes klart at Norge ikke klarte å gjøre seg til den foregangsnasjonen Boyesen og Vigander mer allment hadde sett for seg at man burde være.

Når det ble som det ble, er trolig en viktig årsak til dette at prosjektet nokså raskt endret karakter fra å være et eksperimentelt forsøksprosjekt med en avgrenset og nokså homogen kohort, til å mer bli et skolenettverk med langt mer pragmatiske holdninger når det kom til selve undervisningspraksisen. Et uttrykk for dette er den store veksten $\mathrm{i}$ antall land og institusjoner. Fra å avgrense prosjektet til 33 "secondary schools" ved oppstarten, var antallet i 1958 steget til 186 institusjoner, deriblant også lærerutdanningsinstitusjoner. Siden kom også grunnskoler og barnehager til. Målet om å forske seg frem til en "best practice", som mer eller mindre sømløst kunne overføres på tvers av nasjoner, var dermed i stor grad forlatt før man i det hele tatt hadde rukket å fullføre forsøkene i Norge. Det som fra 1957 fikk navet Associated Schools Project in Education for International Understanding and Co-operation (ASPRO), var et annet prosjekt enn Norge hadde inngitt seg med i 1953.

Om noen hadde håpet at Norge skulle gjenta suksessen med Haakon Viganders Mutual revision, og lage en rapport som kunne gi samme innflytelse innenfor Unescoforsøkene, er uvisst. Uansett synes det klart at når Faaland og Vignaders Educational Experiments kom ut på engelsk i 1962, var toget gått for lenge siden. Norge hadde da også i praksis avsluttet sitt engasjement, og ingen av de norske skolene var lenger aktive innenfor ASPRO. Slik fikk Norge heller ikke utnyttet det potensialet som kunne ha lagt i Vigander som en "foreign relations entrepeneur" og døråpner. Det er heller ingenting i arkivet etter nasjonalkommisjonen som tyder på at noen i forsøkskomiteen eller andre ytret et ønske om å fortsette det norske engasjementet. Kanskje kan vi fra Faaland og Viganders oppsummering også fra lærernes side lese ut en viss tretthet, der de avsluttet med følgende formaning: "Det må understrekes at slike forsøk, likegyldig klassetrinn og arbeidsform, bare bærer helt fram dersom alle deltakende lærere med en viss glød og pedagogisk håndlag går inn for å nå et godt resultat i samsvar med målsettingen." ${ }^{103}$

Dette gjorde også at Unesco-forsøkenes mulighet til å virke "disiplinerende" på norsk skolepolitikk trolig var begrenset. Likevel kan det ikke kan avvises at forsøkene, i kraft av de fremstående aktørene som representerte dem, og de store ressursene som ble langt ned, kan ha bidratt til å fokusere et norsk selvbilde i disse spørsmålene, og sendt signaler om hva som var viktig og riktig i skoleutvikling, både med henblikk på internasjonal forståelse og pedagogikkens lederrolle.

103 Faaland og Vigander (1960), 61. 


\section{Adelskap forplikter}

Artikkelen viser hvordan Unesco-forsøkene i Norge i 1953-1959 ble rammet inn av en bredere norsk satsing på å bygge kulturelle relasjoner med utlandet, og beskriver hvordan enkeltaktører agerte og bidro i dette arbeidet fra ulike institusjonelle kontekster. Dette var en satsing som rommet to motiver: Å skape et positivt bilde av Norge i omverden og å forebygge konflikt. Til grunn lå forestillingen om en særegen norsk fredsnasjon, som forpliktet Norge til å spille en fredsforebyggende rolle på verdensscenen. Særlig så man for seg at Norge kunne spille en slik rolle med utgangspunkt i et velutviklet skole- og utdanningssystem, og å promotere dette ble derfor en sentral del av satsingen.

Her passet Unesco-forsøkene godt inn. De representerte både en arena for å forebygge konflikt, og å skape et positivt bilde av Norge internasjonalt ved å holde frem det norske skole- og utdanningssystemet. Også innsatsen i Unesco-forsøkene var motivert ut fra forestillingen om at Norge hadde særlige forutsetninger for å lykkes, og at Norge dermed var forpliktet til å bidra. Organisatorisk ble Unesco-forsøkene derfor tidlig innlemmet $i$ et pågående arbeid med å bygge kulturelle relasjoner, hvor det var tette forbindelser mellom Kontoret for kulturelt samkvem, KUD og Nasjonalkommisjonen for Unesco, som hadde ansvar for Unesco-forsøkene.

Einar Boyesen var her en sentral aktør og bindeledd. Som leder for Skoleavdelingen i KUD, var han personlig og hans avdeling aktive bidragsytere til Kontoret for kulturelt samkvem sitt arbeid med å promotere det norske skole- og utdanningssystemet overfor utlandet. Han sto også som eksponent for en skoleutvikling basert på pedagogisk vitenskap. Unesco-forsøkenes vitenskapelige profil, gjorde at de representerte en arena for å vise frem norsk pedagogisk forskning, og den norske skolen som moderne og forskningsbasert.

Men Boyesen agerte i denne sammenhengen også ut fra en tradisjon for nordisk samarbeid på skolefeltet som hadde røtter tilbake i mellomkrigstiden, ikke minst gjennom foreningen Norden. Også lederen for Unesco-forsøkene i Norge, Haakon Vigander, understreker dette. Begge hadde vært aktive i foreningen Norden, og det var en klar forestilling hos de to at man i Norden hadde lyktes regionalt med mye av det Unesco nå ønsket å oppnå globalt. Det er nærliggende å tenke seg at den positive oppmerksomheten som det nyopprettede Unesco viet til Foreningen Nordens arbeid, og som Vigander sto som ambassadør for, må ha forsterket denne forestillingen. Boyesens forsøk på å få til et Nordisk samarbeid omkring Unesco-forsøkene må sees i lys av dette. Mer enn bare å promotere Norge og norsk skole, var det her en nordisk modell for fredelig sameksistens man ønsket å vise frem. Tanken synes langt på vei å ha vært at de nordiske landene satt på nøkkelen til Unescos suksess. Dersom Unesco implementerte globalt de verdier og metoder som de nordiske landene gjennom lengre tids utprøving hadde kommet frem til seg imellom, regionalt, ville Unesco lykkes. 


\section{Referanser \\ Trykte kilder}

Det 5. nordiske undervisningsministermøde i København 7-10. februar 1954. Dagsordenens punkt 2: Co-ordinated Experimental Activities in Schools of Member States of Unesco. København: J. H. Sschultz, 1954, 83-90.

Den Høgre Skolen, 1956.

\section{Riksarkivet}

NKOM 1953-1955. Den norske Nasjonalkommisjonen for UNESCO, Serie Da, Saksarkiv, Eske 32, Mappe Skoleforsøkene generelt 1953-1955.

NKOM 1956-1959. Den norske Nasjonalkommisjonen for UNESCO, Serie Da, Saksarkiv, Eske 32, Mappe Skoleforsøkene generelt 1956-1959.

\section{Unesco/Unescodoc}

Disse kildene er alle tilgjengelig digitalt i Unescos arkivdatabase Unescodoc: https:// unesdoc.unesco.org/home

Unesco, A Handbook for the Improvement of Textbooks and Teaching Materials: As Aids to International Understanding. Paris: Unesco, 1949.

Unesco, "Experts Study History Textbook Improvement for Unesco Programme." UNESCO Courier III, no. 10, 24 Oktober 1950.

Unesco, Better History Textbooks. Paris: Unesco, 1951.

Unesco. Bilateral Consultations for the Improvement of Textbooks. Paris: Unesco, 1953.

Unesco, Education for Living in a World Community: Co-ordinated Experimental Activities in Schools of Member States; General Preliminary Information, ED/127. Paris: Unesco, 1953.

Unesco, Co-ordinated Experimental Activities in Education for International Understanding and Co-operation: Interim Report; Activities in 1955 and 1956 ED/149. Paris: Unesco, 1956.

Unesco, Unesco Associated Schools Project in Education for International Understanding: Report on Experimental Projects Carried out in Norwegian Secondary Schools, 1954-1956. Paris: 16 April, 1958, WS/038.87 (Unescodoc).

Unesco, International Understanding at School. An Account of Progress in Unesco's Associated Schools Project. Leiden: Unesco, 1965.

Unesco, Unesco Associated Schools Project Network (ASPnet) Historical Review 1953-2003. Paris: Unesco, 2003.

Unesco, UNESCO Associated Schools Network: guide for national coordinators. Paris: Unesco, 2018.

\section{Stortingsdokumenter}

Stortingsproposisjon nr. 1 (1950), "Statsbudsjettet for budsjetterminen 1950-1951." Utenriksdepartementet, utenriksrepresentasjonen og andre utenriksformål. Kap. 117, Norsk institutt for kulturelt samkvem med utlandet, Stortingsforhandlinger.

Stortingsmelding nr. 17 (1956), Om Norges deltakelse i De Forente Nasjoners Organisasjon for Undervisning, Vitenskap og Kultur (UNESCO).

St. meld. nr. 17 (1956), 2; St. meld nr. 78 (1956): Om virksomheten ved Kontoret for kulturelt samkvem med utlandet 1. julig 1950-30. juni 1956. 


\section{Litteratur}

Angell, Svein Ivar. Den svenske modellen og det norske systemet: Tilhøvet mellom modernisering og identitetsdanning i Sverige og Noreg ved overgangen til det 20. hundreåret. Oslo: Samlaget, 2002.

Angell, Svein Ivar. "Norges nasjonspromotering - mellom nation branding, cultural diplomacy og økonomisk nasjonalisme." Den jyske historiker, nr. 126 (2010), 40-59.

Angell, Svein Ivar. "Norge og omverdenen 1945-2010: Fra kulturpleje til omdømmeforvaltning." Økonomi \& Politik, nr. 4 (2014), 26-36.

Angell, Svein Ivar. "The Office for Cultural Relations: Representing Norway in the Post-War Period." I Histories of Public Diplomacy and Nation Branding in the Nordic and Baltic Countries: Representing the Periphery, red. Louis Clerc, Nikolas Glover og Paul Jordan. Leiden/Boston: Brill Nijhoff, 2015).

Angell, Svein Ivar. "The Result of Gradual Development of Democratic Idealism:” Education and Images of Norway in the Post-War Period. Forthcoming.

Borgen, Christina. Asssociated Schools Project (ASP): En underøkelse av UNESCOs skolenettverk i Norge. Universitetet i Oslo: Hovedoppgave i Pedagogikk, 1996.

Boyesen, Einar. "Norway's Educational System." i A Record of the Hundorp Conference for British and Norwegian Teachers, August 1946, 9-25. Oslo: Gyldendal, 1948.

Clerc, Luis og Nikolas Glover. "Representing Small States in Northern Europe: Between Imagined and Imaged Communities." I Histories of Public Diplomacy and Nation Branding in the Nordic and Baltic Countries: Representing the Periphery, red. Louis Clerc, Nikolas Glover og Paul Jordan, 3-20. Leiden/Boston: Brill Nijhoff, 2015.

Eckert, Georg, "Internationale Schulbuchrevision." Internationale Schulbuchforschung, no. 6 (1960), 399-415.

Elmersjö, Henrik Åström, Norden, nationen och historien: Perspektiv på föreningarna Nordens historieläroboksrevision 1919-1972. Lund: Nordic Academic Press, 2013.

Faaland, Josef og Haakon Vigander. Tre års undervisningsforsøk etter Unesco-tiltak. Oslo: Gyldendal, 1960.

Faaland, Josef og Hakon Vigander. Educational Experiments Carried out over a Three-Year Period under a UNESCO Scheme. Oslo: Unesco and the Norwegian Government, 1962.

Glover, Nikolas. National Relations: Public Diplomacy, National Identity and the Swedish Institute, 1945-1970. Lund: Nordic Academic Press, 2011.

Helsvig, Kim. Reform og rutine: Kunnskapsdepartementets historie 1945-2017. Oslo: Pax, 2017.

Holmboe, Haakon, "Unesco-forsøk i skolen." Norsk skole - Opplysnings og kunngjøringsblad for skoleverket 3, no. 11 (1957), 163-67.

Hove, Olav. An Outline of Norwegian Education. Oslo: Royal Norwegian Ministry of Foreign Affairs, Office for Cultural Relations and Royal Norwegian Ministry of Church and Education, 1955 - nytt opplag i 1958.

Hovland, Brit Marie. Historie som skolefag og dannelsesprosjekt 1889-1940: En historiografi ut fra folkeskolens historielorebøker. Oslo: Universitetet i Oslo 2016. Høyvik, Ragnhild Eitungjerde. "Fram fra skjoldets skygge" Norsk arbeid med kulturrelasjoner overfor utlandet 1945-1973. Masteroppgave, Universitetet i Bergen 2014. 
Kjærsgaard, Kristine. "A Public Diplomacy Entrepreneur: Danish Ambassador Bodil Begtrup in Iceland, Switzerland and Portugal, 1949-1973." I Histories of Public Diplomacy and Nation Branding in the Nordic and Baltic Countries: Representing the Periphery, red. Louis Clerc, Nikolas Glover og Paul Jordan, 102-22. Leiden/ Boston: Brill Nijhoff, 2015.

Luntinen, Perrti. "School History Textbook Revision by and under the Auspices of UNESCO, Part 1." Internationale Schulbuchforschung 1988, no 4 (1988).

Lycke, Ingeborg. Adult Education in Norway. Oslo: Royal Norwegian Ministry of Foreign Affairs, Office for Cultural Relations, 1957.

Nordland, Eva. Evaluering av de norske Unesco nettverksskolene, Rapport nr. 2. Oslo: Pedagogisk forskningsinstitutt, Universitetet i Oslo 1990.

Sandven, Johs. "Elevenes reaksjon på skolens program, arbeidsmetode og arbeidsorden." Scandinavian Journal of Educational Research 3, no. 1 (1957a), 181-213.

Sandven, Johs. "Educational Research in Norway: The Development Since 1950." International Review of Education 3, no. 3 (1957b), 373-77.

Schweisfurth, Michele. "Learning to Live Together: A Review of Unesco's Associated Schools Project Network." International Review of Education 51, no. 2/3 (2005), 219-34.

Suárez, David F., Francisco O. Ramirez, og Jeong-Woo Koo. "UNESCO and the Associated Schools Project: Symbolic Affirmation of World Community, International Understanding, and Human Rights." Sociology of Education 82, no. 3 (2009), 197-216.

Sæle, Christian. Den rette historien: Lærebokkritikk som historiepolitisk redskap. Bergen: Universitetet i Bergen, 2013.

Teige, Elisabeth. "Kan demokrati læres?" I Nye stemmer i norsk pedagogisk humanioraforskning, red. Tone Kvernbekk og Lars Løvlie, 179-201. Bergen: Fagbokforlaget, 2011a.

Teige, Elisabeth: "Citizenship Education and the Rebuilding of Europe after World War II: The Case of Norway." Virteljahrschrift für Wissenschaftliche Pedagogik, no. 3 (2011b).

Thue, Fredrik W. In Quest of a Democratic Social Order: The Americanization of Norwegian Social Scholarship 1918-1970. Oslo: University of Oslo, 2005.

Vigander, Haakon. Historieundervisningen og mellomfolkelig forståelse: Foredrag holdt i Nobelsalen, Oslo, den 28. februar 1946. Oslo: Norsk gruppe av internasjonal kvinneliga for fred, 1946.

Vigander, Haakon. "The Teaching of History and International Understanding." I A Record of the Hundorp Conference for British and Norwegian Teachers, August 1946, 79-118. Oslo: Gyldendal, 1948.

Vigander, Haakon. Mutual Revision of History Textbooks in the Nordic Countries. Paris: Unesco, 1950.

Vigander, Haakon. "Deutsche Lehrbücher und die Darstellung der deutschnorwegischen Beziehungen im Zweiten Weltkrieg." Internationales Jahrbuch für Geschichtsunterricht 8, 1 January 1961, 276-79.

Wiley, George M. The Organisation and Administration of the Educational System of Norway. Oslo: Royal Norwegian Ministry of Foreign Affairs, Office for Cultural Relations and Royal Norwegian Ministry of Church and Education, 1955. 